\title{
The occurrence of muskrat Ondatra zibethicus in central and eastern Poland in the period $1996-2007^{\star}$
}

\section{Zmiany w występowaniu piżmaka Ondatra zibethicus w centralnej i wschodniej Polsce w latach 1996-2007}

\author{
Jerzy Romanowski' ${ }^{1}$ Karolina Karpowicz ${ }^{2}$ \\ ${ }^{1}$ Faculty of Biology and Environmental Sciences, Cardinal Stefan Wyszynski University in Warsaw, Poland \\ ${ }^{2}$ Centre for Ecological Research in Dziekanów Leśny, Polish Academy of Sciences, Poland \\ ORCID: JR https://orcid.org/0000-0003-1050-6403•j.romanowski@uksw.edu.pl
}

\begin{abstract}
Muskrat, Ondatra zibethicus (L. 1766), is an introduced species to European fauna. It is widespread in Poland, however, signs of its decline were observed in the last decades. While most of the information on muskrat is based on questionnaires and bag record, in this paper results of field census for muskrat signs (tracks and faeces) at a total of 1554 sites are presented. Signs of muskrats were present at $19.5 \%$ of 1111 sites surveyed from 1996-1998, and at $5.3 \%$ of 413 sites surveyed in 2007 . Muskrats inhabited mostly small and medium rivers in the western part of the study area. The decrease in the occurrence of the species over a study period is the best document by a significant reduction in the frequency of muskrat records at the 249 sites surveyed in 1996-1998 (present at 44\% sites) and 2007 (7\%). The decline of the muskrat population is most probably the effect of increasing predation by American mink Neovison vison.
\end{abstract}

Keywords: muskrat, semiaquatic mammals, Ondatra zibethicus, American mink, Neovison vison

Streszczenie: Piżmak Ondatra zibethicus (L. 1766), jest gatunkiem introdukowanym w Europie. Jest rozpowszechniony w całej Polsce, jednak w ostatnich dziesięcioleciach zaobserwowano załamanie jego liczebności. Większość dotychczasowych informacji o występowaniu gatunku opartych było o sprawozdania o stanie zwierzyny Polskiego Związku Łowieckiego. W niniejszej pracy prezentowane są wyniki prac terenowych, w których poszukiwano śladów obecności piżmaka na 1554 stanowiskach badawczych w centralnej i wschodniej Polsce. Ślady obecności piżmaków stwierdzono w 19.5\% spośród 1111 stanowisk przebadanych w 1996-1998, i w 5.3\% spośród 413 stanowisk przebadanych w 2007 r. Większość stwierdzeń piżmaków znajdowała się w zachodniej części terenu badań. Spadek liczebności gatunku odzwierciedlony jest w istotnym zmniejszeniu się częstości stwierdzeń piżmaków z 44\% w 1996-1998 do 7\% w 2007 r. na 249 stanowiskach badanych w obu okresach. Spadek liczebności piżmaka spowodowany jest przypuszczalnie drapieżnictwem norki amerykańskiej Neovison vison.

Słowa kluczowe: piżmak, ssaki ziemnowodne, Ondatra zibethicus, norka amerykańska, Neovison vison

"This article was originally published in Polish as Romanowski, Jerzy, i Karolina Karpowicz. 2013. "Zmiany w występowaniu piżmaka Ondatra zibethicus w centralnej i wschodniej Polsce w latach 1996-2007." Studia Ecologiae et Bioethicae 11(1): 49-61. The translation of the article into English was financed by the Ministry of Science and Higher Education of the Republic of Poland as part of the activities promoting science Decision No. 676/P-DUN/2019 of 2 April 2019. Translation made by GROY Translations. 


\section{Introduction}

Muskrat, Ondatra zibethicus (L. 1766), is a rodent of vole family. This amphibious mammal is native to North America, where it is common almost all over the continent. It inhabits banks of water environments (rivers, streams, swamps, drainage ditches, lakes and fishponds). Muskrat is mainly fed on plants, less frequently on molluscs and crustaceans (Errington 1963).

The species was brought to Europe in the early 20th century for breeding purposes because of its precious fur. Animals often escaped from inadequately secured farms, starting wild populations on this continent. The natural expansion of the population from the areas of the Czech Republic and Slovakia, as well as from Germany, was crucial for the colonisation of Poland by muskrats. Quite frequent escapes from the farms located in the country, to which the animals were brought in the 1920s and 1930s, also had an impact. Muskrat spread in Poland from south to north along the main rivers (the Vistula, the Oder and the Warta), which were important ecological corridors for the animal (Nowak 1966).

The first reports about the appearance of this rodent in post-war Poland date back to 1924 and mention Kopacz near Złotoryja and the valleys of the following rivers: Orlica, Nysa Kłodzka, Biała Lądecka, and also Kłodzko district. Muskrats probably got to Polish lands from the Czech Republic through the Orlica river valley to Bystrica Klodzka district, and from there to the Odra river. Already in the early 1940s, there was a dense population of this species in the south of the country, and numerous localities in central and northern Poland (mainly in the Vistula Valley) were known. Until the end of the 1950s, the numerous population of muskrats covered almost the entire area of the country (Nowak 1966). A similar phenomenon was observed in Finland (Artimo 1960), where the animal colonised the whole country in less than 30 years.

The muskrat's area of occupancy covers the whole of Poland (Pucek and Raczyński 1983). Until recently, the species was con- sidered common, e.g. Grabińska (2007) describes that it "occurs at almost every water reservoir". In recent years, a decline in the number of muskrats has been observed in Poland. A decrease in the population of this rodent in our country was recorded as early as in the eighties in the areas which American mink, Mustela vison, entered at that time (Schreber 1777). In turn, in areas not colonised by this predator, the population of muskrat did not change much (Brzeziński and Marzec 2003).

The article aims to compare the results of research on the occurrence and the environmental requirements of muskrats in 1996-2007 to determine the trend of changes in the abundance and area of this species in central and eastern Poland.

\section{Study area}

The research was conducted in central and eastern Poland (Kujawy, Mazowsze, Podlasie and Lublin area). Most of the research area is located in the Vistula river basin, only the Ner River, Lake Gopło and Bachorze Canal on the western edge of the research area are connected to the Odra river basin. The main rivers are the Vistula, Bzura, Bug and Wieprz (Fig. 1). In the northern part of the research area, there are numerous hills and lakes of different sizes. In the south, in turn, there are plains with a well-developed river network (the lakes are relatively rare here). Land use in the research area is also diversified. The western part is dominated by agricultural land (72\% of the area), and the settlement network is well developed (Bagdziński 1997). The central part of the described area has a high population density (638 persons $/ \mathrm{km}^{2}$ with a national average of 123 person $/ \mathrm{km}^{2}$ ), high concentration of industry and a small share of agricultural land (52\% of the area) (Sosnkowski and Gołecki 1997). On the other hand, the eastern part of the study area is typically agricultural (high share of agricultural land - approx. $70 \%$ of the area and relatively low population density - 60-80 persons $/ \mathrm{km}^{2}$ ) (Starczewski 1995; Kot 1997). 


\section{Material and methods}

Field research was conducted in 1996-2007 together with otter inventory. The so-called standard method was used there. The method generally consists in searching the shoreline sections of the examined watercourses and reservoirs (hereinafter referred to as "sites") for the signs of presence (tracks, faeces and marking sites) of otter and other mammals associated with the aquatic environment (including muskrat), until signs of otter's existence are found or until the researcher has passed six hundred metres (Lenton, Chanin, and Jefferies 1980; Romanowski 2006). During the study, a minimum of $200 \mathrm{~m}$ bank section was penetrated at each site in search of traces of muskrats.

The sites were selected based on topographic 1:100,000 scale maps, taking into account the presence of watercourses and reservoirs and the availability of their banks. The search was most often started under bridges, which are the place to find the larg- est number of traces of otters and muskrats. The bank inspection was carried out at a distance of 200 to $600 \mathrm{~m}$. The places where signs of muskrat presence (traces and excrement) were found were called positive sites.

A total of 1554 sites were examined, but their number and location often differed in subsequent years: 1996-1998 - 1111 sites (Kujawy, Mazowsze and Podlasie) (Fig. 1); 1999 - 10 sites (section of the Vistula between Płock and Nowy Dwór Mazowiecki), 2003 - 404 sites in Lublin region, 2004 - 42 sites (the Vistula valley between Warsaw and Płock), 2007 - 413 sites (near Warsaw, Włocławek and Łódź) (Fig. 2). The comparison of the results for 249 sites tested in two periods (1996-1998 and 2007) was used to determine the differences in the prevalence of muskrats in the studied area. Significance of differences between the results obtained in positive and negative sites were checked using chisquared $\left(\mathrm{X}^{2}\right)$ test.

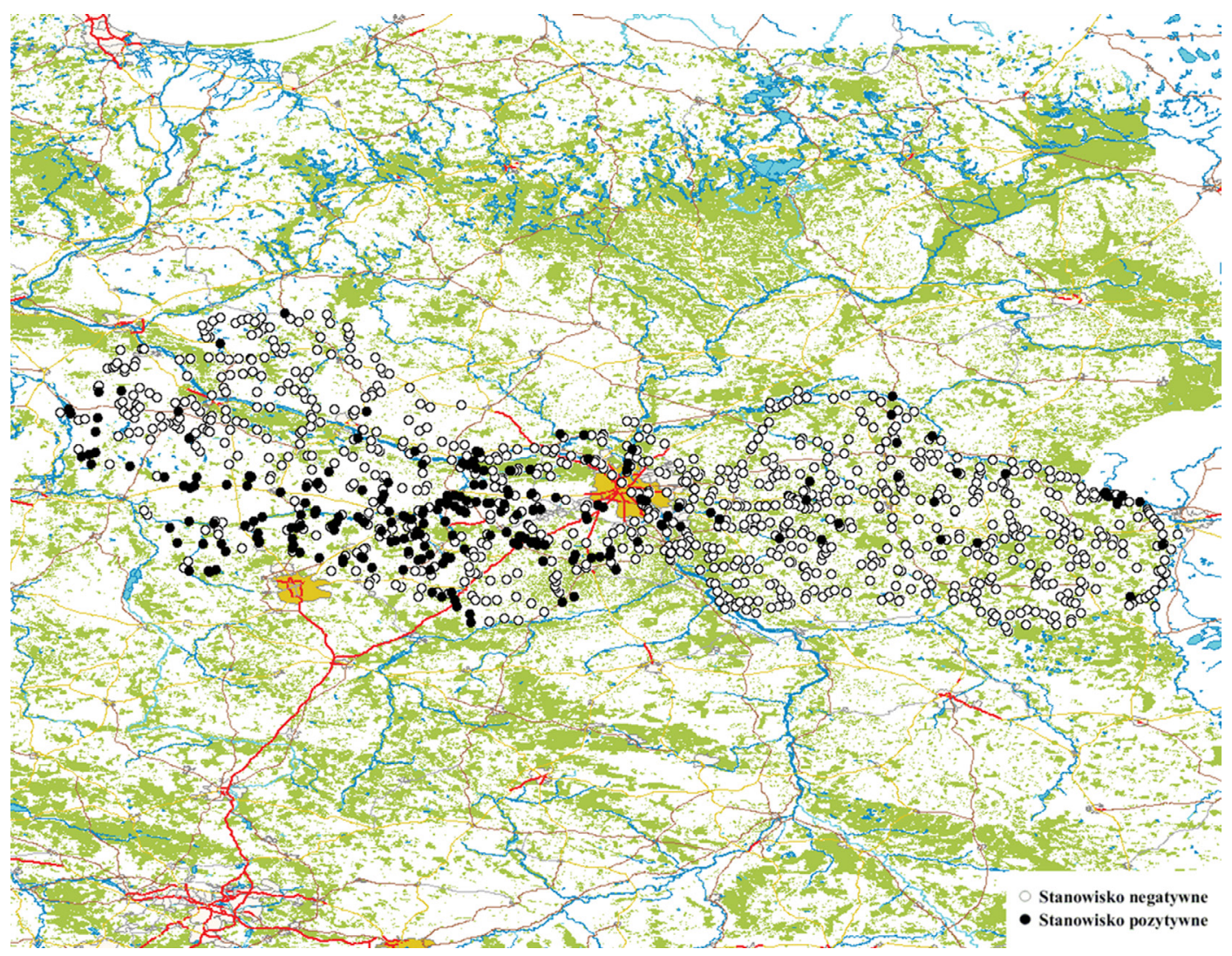

Fig. 1. Presence of muskrat in the area studied in 1996-1998 (white dots indicate the negative sites and black dots indicate positive sites). 


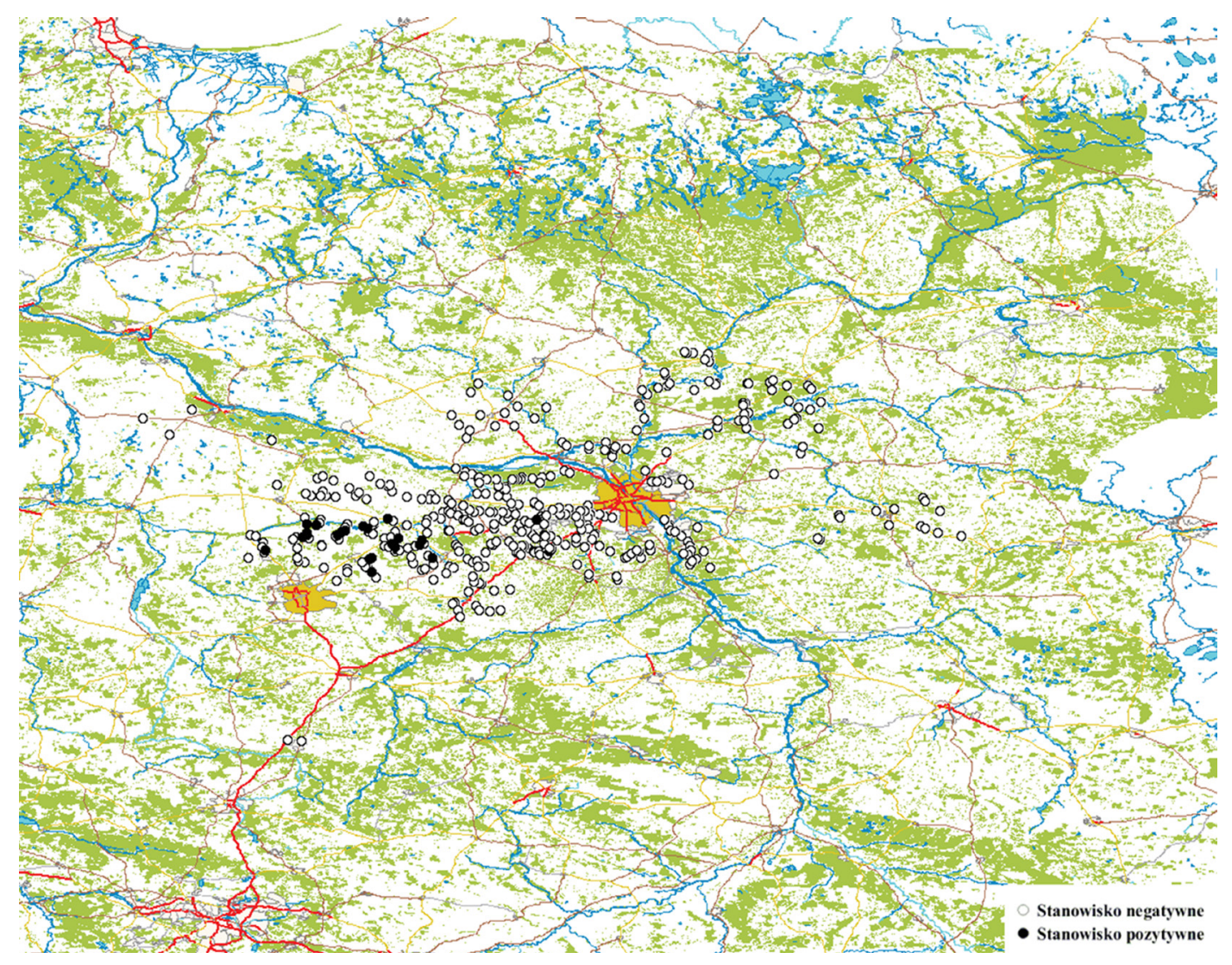

Fig. 2. Presence of muskrat in the studied area in 2007 (white dots indicate the negative sites and black dots indicate positive sites).

For each site investigated in 1996-1998, selected environmental parameters were described: presence and share of trees and bushes, the width and depth of the watercourse or reservoir (statistical analysis using $X^{2}$ test, trough regulation, water cleanliness, number of buildings up to $30 \mathrm{~m}$ away from the bank and surrounding sites within a $300 \mathrm{~m}$ radius (presence of forests, meadows, pastures, farmland, buildings and other water environments) (statistical analysis using Kruskal-Wallis nonparametric test).

\section{Results}

Signs of the presence of muskrats were found in 216 (19.5\%) out of 1111 sites investigated in central and eastern Poland in 1996-1998. Most of the traces found were located in the western part of the research area, south of the Vistula (Fig. 1). The most important watercourses inhabited by muskrats include the following: Bzura with its tributaries (among others: Skierniewka, Rawka, Słudwia and Pisia), Łasica canal in Kampinos Forest and the Okrzesza nearby Mszczonów. The presence of muskrats was also found in two of the 10 sites searched in 1999 on the banks of the Vistula between Płock and Nowy Dwór Mazowiecki. In the course of research in the area of Podlasie and Lublin region (eastern Poland) in 2003, traces of muskrats were found in 2 $(0.5 \%)$ out of the 401 sites searched (both from around the Wieprz River). During the exploration carried out at 42 sites on the Vistula (between Warsaw and Płock) and the lower Bzura in 2004, no traces of muskrats were found. During subsequent studies in central Poland, traces of these rodents were found in $22(5.3 \%)$ out of the 413 sites examined in 2007. The place of their occurrence was the Bzura river at the area of Łódź, with its several tributaries (including Skierniewka). 
The comparison of the differences in the frequency of recorded muskrat presence carried out only for 249 sites tested during both test periods (1996-1998 and 2007) shows a decrease in the frequency of found muskrat traces from $44 \%$ to only about $7 \%$ of the sites tested (Table 1). The same studies document an increase in the prevalence of other species of amphibian mammals (otters and beavers) during the discussed period (Table 1).

The study carried out in 1996-1998 showed certain relationships between the presence of muskrats and some elements of the environment. The average width of watercourses at positive sites was $5.57 \mathrm{~m}$ (SD $=4.8)$, while the width of watercourses at all searched points was $47.7 \mathrm{~m}(\mathrm{SD}=$ 201.22) on average, and $70.5 \mathrm{~m}(\mathrm{SD}=247.1)$ at negative sites (Table 2). The depth of the stream also proved to be an important element of the environment. The presence of muskrats was found much more often over rivers and streams with a depth exceeding $0.5 \mathrm{~m}$ than it would be expected from their share in the total number of studied sites

Table 1. Changes in the number of recorded signs of muskrats, otters and beavers at 249 sites studied in 1996-1998 and 2007 in central Poland.

\begin{tabular}{|l|c|c|c|c|c|c|c|}
\hline \multirow{2}{*}{} & \multicolumn{2}{|c|}{$1996-1998$} & \multicolumn{2}{c|}{2007} & \multicolumn{2}{|c|}{} \\
\cline { 2 - 8 } & $\mathrm{n}$ & $\%$ & $\mathrm{n}$ & $\%$ & $\mathrm{X}^{2}$ & $\mathrm{df}$ & $\mathrm{p}$ \\
\hline Otter & 97 & 38.96 & 220 & 88.35 & 91.415 & 1 & $<0.0001$ \\
\hline Muskrat & 110 & 44.18 & 17 & 6.83 & 131.311 & 1 & $<0.0001$ \\
\hline Beaver & 21 & 8.43 & 51 & 20.48 & 14.6127 & 1 & 0.0001 \\
\hline
\end{tabular}

Table 2. Characteristics of selected environmental parameters at the sites studied in 1996-1998.

\begin{tabular}{|c|c|c|c|c|c|c|c|}
\hline \multicolumn{2}{|l|}{ Site description } & Positive sites & Negative sites & $\begin{array}{l}\text { Sites } \\
\text { total }\end{array}$ & $x^{2}$ & $\mathrm{df}$ & $\mathrm{p}$ \\
\hline \multicolumn{8}{|l|}{ Bank share (\%): } \\
\hline \multirow{2}{*}{ wooded } & $x$ & 27.9 & 28.5 & 28.4 & 0.443 & 1 & 0.5059 \\
\hline & S.D. & 28.5 & 27.4 & 27.6 & & & \\
\hline \multirow{2}{*}{ bushy } & $x$ & 14.0 & 13.5 & 13.6 & 0.051 & 1 & 0.8217 \\
\hline & S.D. & 19.2 & 22.0 & 19.7 & & & \\
\hline \multirow{2}{*}{ open } & $x$ & 58.3 & 57.8 & 57.9 & 0.062 & 1 & 0.8028 \\
\hline & S.D. & 33.8 & 33.7 & 33.7 & & & \\
\hline \multirow{2}{*}{ Watercourse width (m): } & $x$ & 5.6 & 70.5 & 47.7 & 6.340 & 1 & 0.0118 \\
\hline & S.D. & 4.8 & 247.1 & 201.2 & & & \\
\hline \multirow{2}{*}{$\begin{array}{l}\text { Watercourse depth } \\
(\mathrm{m}) \text { : }\end{array}$} & $x$ & 0.9 & 0.6 & 0.7 & 5.110 & 1 & 0.0238 \\
\hline & S.D. & 0.6 & 0.5 & 0.6 & & & \\
\hline Bank engineering: & $\%$ & 52.3 & 50.0 & 50.5 & 0.376 & 1 & 0.5396 \\
\hline \multicolumn{8}{|l|}{ Water pollution: } \\
\hline heavily polluted & $\%$ & 15.0 & 8.0 & 9.6 & 8.629 & 1 & 0.0033 \\
\hline polluted & $\%$ & 45.5 & 27.9 & 32.0 & 21.876 & 1 & $<0.0001$ \\
\hline clean & $\%$ & 39.5 & 64.0 & 58.4 & 38.229 & 1 & $<0.0001$ \\
\hline Presence of buildings: & $\%$ & 19.1 & 19.3 & 19.3 & 0.016 & 1 & 0.8980 \\
\hline
\end{tabular}


(positive sites: $=0.9 \mathrm{~m}, \mathrm{SD}=0.6$; negative sites: $=0.6 \mathrm{~m}, \mathrm{SD}=0.5$; total sites: $=0.7$ $\mathrm{m}, \mathrm{SD}=0.6)$. It was also observed that the positive study sites were characterised by a lower share of clean watercourses in comparison with negative study sites $(39.5 \%$ and $64.0 \%$, respectively). No statistically significant differences between the positive and negative sites were noted in terms of trough regulation, the share of trees and bushes and the presence of buildings on the bank (Table 2). Also, the presence of forests, meadows, pastures, fields, construction sites, fishponds and other water environments within a radius of 300 meters from the sites studied did not differ significantly between positive and negative sites.

\section{Discussion}

The existing information on the occurrence of muskrat in Poland, based on reports on the condition of game in hunting districts of the Polish Hunting Association, indicated a decrease in the population of this species at the beginning of the 21st century (Grabinska 2007; Kamieniarz and Panek 2008). The results obtained in this study based on field research show that we are currently dealing with a significant decrease in the population of this rodent, which is also confirmed by data on muskrat hunting in 1981-2007 (Brzeziński et al. 2010).

The decrease in the number of muskrats in Poland was recorded already at the beginning of the 1980s, and the most rapid changes occurred at the end of the decade. It coincided with the appearance of the American mink (a natural enemy of muskrat) in our country. It is not without significance that this decrease was greatest in areas with the highest population of mink, which suggests that mink predation is the main reason for the withdrawal of this rodent from Poland (Brzeziński et al. 2010). However, the importance of other factors, such as pathogenic organisms (including parasites), should not be ignored, as a decrease in the muskrat population (although not as significant) was also observed in areas where this predator was not found (Brzeziński and Marzec 2003).
It is also possible that the observed process is the result of the simultaneous action of predatory pressure and additional factors. The most important factor here may be the reduction of the groundwater level. Studies conducted in Canada showed that with low water levels in reservoirs, the American mink exerts much more pressure on the muskrat population as it is easier for it to catch this rodent (Clark and Kroeker 1993). In the studies conducted, the presence of muskrats was recorded more frequently on smaller, more polluted watercourses. This may indicate environmental selectivity of the species or the selective influence of mink predation.

Currently, the American mink population is still in the expansion phase. Therefore, its size is relatively high (Brzeziński and Marzec 2003). For this reason, it exerts strong pressure on the populations of its prey, which has not yet developed effective defence mechanisms. An example of this phenomenon can be the results of research which showed that the American mink has contributed to a significant decline in the population of waterbirds in many regions of Poland (Bartoszewicz and Zalewski 2003; Brzeziński and Marzec 2003), as well as caused a decrease in the number of rodents in the UK (Carter and Bright 2003).

Even though the muskrat naturally co-exists with the American mink in North America and constitutes one of its primary prey, in areas where the rodent was not under pressure from this predator (and thus did not develop adequate defence mechanisms), the appearance of the mink puts strong pressure on the muskrat population, which results in a significant decline or collapse of the population (Balerstet et al. 1989; Soper and Payne 1997; Bartoszewicz and Zalewski 2003). Most probably, this very phenomenon is currently observed in our country.

In the coming years the population of American mink in Poland will likely stabilise, and several decades of coexistence of both species will result in muskrats developing behaviours conducive to avoiding the predation of mink. This will cre- 
ate a dynamic equilibrium between these species, as is the case in North America, where the muskrat and mink have 8-9year cycles of abundance (Erb, Boyce, and Stenseth 2001; Viljugrein et al. 2001), and between foxes and muskrats in Sweden (Danell 1985).

\section{Bibliography}

Artimo, Atso. 1960. "The dispersal and acclimatizations of the muskrat, Ondatra zibethicus (L.) in Finland." Papers on Game Research 21: 1-101.

Bagdziński, Stanisław L. 1997. Środowisko przyrodnicze w województwie włocławskim. Włocławek: Włocławskie Towarzystwo Naukowe.

Balerstet, Teresa. 1989. Biometria $i$ struktura populacji pizmaka Ondatra zibethicus (Linneus, 1766) w rezerwacie "Jezioro Drużno". Praca magisterska. Katedra Ekologii i Zoologii Kręgowców Uniwersytetu Gdańskiego.

Bartoszewicz, Magdalena, and Andrzej Zalewski. 2003. "American mink, Mustela vison, diet and predation on waterfowl in the Słońsk Reserve, western Poland." Folia Zoologica 52(3): 225-238.

Brzeziński, Marcin, and Magdalena Marzec. 2003. "The origin, dispersal and distribution of the American mink, Mustela vison, in Poland." Acta Theriologica 48(4): 505-514.

Brzeziński, Marcin, Jerzy Romanowski, Michał Żmihorski, and Karolina Karpowicz. 2010. "Muskrat (Ondatra zibethicus) decline after the expansion of American mink (Neovison vison) in Poland." European Journal of Wildlife Research 56(3): 341-348.

Carter, Steven P., and Paul W. Bright. 2003. "Reedbeds as refuges for water voles ( $\mathrm{Ar}$ vicola terrestris) from predation by introduced mink (Mustela vison)." Biological Conservation 111(3): 371-376. https://doi. org/10.1016/S0006-3207(02)00305-1.

Clark, William R., and Darryl W. Kroeker. 1993. "Population dynamics of Muskrats in experimental marshes at Delta, Manitoba." Canadian Journal of Zoology 71(8): 6201628. https://doi.org/10.1139/z93-228.

Danell, Kjell. 1985. "Population fluctuations of the muskrat in coastal northern Sweden." Acta Theriologica 30(12): 219-227.
Erb, John, Mark S. Boyce, and Nils C. Stenseth. 2001. "Spatial variation in mink and muskrat interactions in Canada." Oikos 93(3): 365-375. https://doi.org/10.1034/j.16000706.2001.930302.x.

Errington, Paul Lester. 1963. Muskrat populations. Ames: Iowa State University Press.

Grabińska, Bożenna. 2007. “Zmienność przestrzenna i czasowa rozmieszczenia ssaków łownych Polski." Dokumentacja Geograficzna 34: 1-67.

Kamieniarz, Robert, i Marek Panek. 2008. Zwierzęta towne w Polsce na przetomie XX $i$ XXI wieku. Czempiń: Stacja Badawcza - OHZ PZŁ w Czempiniu.

Kot, Henryk. 1997. "Informacje ogólne o województwie." W Informator przyrodniczy, wojew ództwo bialskopodlaskie, red. Henryk Kot, 7-8. Siedlce: Zakład Badań Ekologicznych EKOS.

Lenton, E. J., Paul R. F Chanin, and D. J. Jefferies. 1980. Otter survey of England 19771979. London: Nature Conservancy Council.

Nowak, Eugeniusz. 1966. "Rozprzestrzenianie się, liczebność i znaczenie piżmaka, Ondatra zibethicus (L. 1766), w Polsce." Przeglad Zoologiczny 10: 221-237.

Pucek, Zdzisław, i Jan Raczyński. 1983. Atlas rozmieszczenia ssaków w Polsce. Warszawa: Wydawnictwo Naukowe PWN.

Soper, Leah R., and Neil F. Payne. 1997. "Relationship of introduced mink, an island race of muskrat, and marginal habitat." Annales Zoologici Fennici 34: 251-258.

Sosnkowski, Michał, i Bogdan Gołecki. 1997. Raport o stanie środowiska w województwie stołecznym warszawskim 1996 roku. Warszawa: Biblioteka monitoringu środowiska.

Starczewski, Cezary. 1995. "Informacje ogólne o województwie." W Przyroda województwa siedleckiego, red. Henryk Kot, 8-10. Siedlce: Zakład Badań Ekologicznych EKOS.

Romanowski, Jerzy. 2006. "Monitoring of the Otter recolonisation of Poland." Hystrix, the Italian Journal of Mammology 17(1): 37-46. https://doi.org/10.4404/hystrix-17.1-4363.

Viljugrein, Hildegunn, Ole C. Lingjaerde, Nils C. Stenseth, and Mark S. Boyce. 2001. "Spatio-temporal patterns of mink and muskrat in Canada during a quarter century." Journal of Animal Ecology 70: 671-682. https://doi. org/10.1046/j.1365-2656.2001.00526.x. 